\title{
Pendayagunaan Alat Bantu Seleksi Koleksi di UPT. Perpustakaan Pusat UNPAD (Studi Tentang Pengembangan Koleksi di Perpustakaan Pusat Universitas Padjadjaran)
}

\author{
Panji Robby R. dan Yunus Winoto \\ Universitas Padjadjaran, Jl. Raya jatinangor Sumedang KM 21 Bandung. \\ Email: yunus.winoto@unpad.ac.id
}

\begin{abstract}
Abstrak
Penelitian ini bertujuan untuk mengetahui pendayagunaan alat bantu seleksi bahan pustaka oleh para petugas perpustakaan dalam kegiatan pengembangan koleksi. Lokasi penelitian ini di perpustakaan pusat Universitas Padjadjaran. Metode yang digunakan dalam penelitian ini menggunakan pendekatan kualitatif dengan jenis penelitian studi kasus. Untuk pengumpulan datanya dilakukan melalui wawancara, pengamatan lapangan dan studi kepustakaan. Berdasarkan hasil penelitian diketahui bahwa 1). Untuk prosedur penyeleksian bahan pustaka dimulai dari berbagai saran, masukan baik lisan maupun tertulis yang masuk ke bagian layanan sirkulasi, layanan referensi maupun layanan majalah. 2). Penggunaan alat bantu seleksi oleh petugas perpustakaan pusat Universtas Padjadjaran belum berjalan secara optimal, artinya dari beberapa alat bantu yang tersedia saat ini alat bantu yang dipergunakan hanya yang berupa katalog penerbit, daftar katalog dalam media internet seperti amazon. com, 3). Alasan pihak perpustakaan pusat Universitas Padjadjaran dalam menggunakan beberapa alat bantu seleksi tertentu seperti katalog penerbit dan katalog dalam media internet yakni faktor kemudahan dalam penggunaan alat bantu tersebut, 4) hambatan perpustakaan pusat Universitas Padjadjaran dalam menggunakan alat bantu seleksi yaitu keterbatasan jumlah tenaga dan kurang lengkap alat bantu seleksi khususnya untuk seleksi bahan pustaka berupa majalah dan bahan non buku.
\end{abstract}

Kata Kunci: pengembangan koleksi, alat bantu seleksi, perpustakaan pusat UNPAD. 


\begin{abstract}
This study aims to determine the utilization of the library material selection tool by the librarians in the collection development activities. The location of this research is in the central library of Padjadjaran University. The method used in this study used a qualitative approach to the type of case study research. For data collection is done through interviews, field observation and literature study. Based on the result of research known that 1). For library selection procedure begins with various suggestions, input both oral and written into the circulation services, reference services and magazine services. 2). The use of the selection tool by the librarian of Universtas Padjadjaran University has not run optimally, meaning that from some tools currently available the tools used only in the form of catalog of publishers, catalog list in internet media such as amazon.com, 3). The reason of the library center of Universitas Padjadjaran in using certain selection tools such as catalog of publisher and catalog in internet media that is factor of easiness in the use of the tool, 4) constraint of library of University of Padjadjaran in using selection tool that is limited of number of manpower and less complete tool Aids selection, especially for the selection of library materials such as magazines and non-book materials.
\end{abstract}

Keywords: collection development, selection tool, central library UNPAD.

\title{
Pendahuluan
}

\section{Latar Belakang Masalah}

Perpustakaan adalah sebuah lembaga yang menyediakan berbagai macam informasi baik berupa buku, majalah, koran bahkan yang berupa bahan non buku (non book material) serta layanan internet. Sudah menjadi tuntutan zaman bahwa informasi sangat dibutuhkan oleh semua orang. Tidak peduli jenis pekerjaan orang itu baik pelajar, mahasiswa, guru, dosen, dokter dan sebagainya. Pada intinya semua orang membutuhkan informasi yang berguna mendukung pekerjaannya sehari-hari, karena dengan adanya informasi kita dapat mengarahkan kegiatan kita dengan baik sesuai dengan tujuan dan pengelolaan kegiatan yang bersangkutan.

Salah satu penunjang dalam mencari sebuah informasi adalah perpustakaan. Informasi memiliki peranan yang sangat penting dalam kehidupan manusia. Hal ini sejalan dengan yang diungkapkan oleh Fastbrook dalam Pawit M Yusup yang mengatakan bahwa: 
"Peranan informasi bukan barang baru di perpustakaan, ia meningkat peranannya sejalan dengan tuntutan masyarakat akan kegunaan informasi itu. Anggota kelompok masyarakat dapat lebih banyak tahu akan informasi dari perkiraan sebelumnya. Informasi yang lebih baik adalah terpasok dan di akses secara cepat sehingga yang demikian itu sangat di perlukan guna mencukupi segala peristiwa dan kecenderungan kondisi masyarakat yang semakin berubah". (Yusup, 1990:4)

Informasi tidak hanya memegang peranan penting dalam kehidupan manusia, tetapi juga dapat membantu manusia dalam mengembangkan pengetahuannya. Melalui informasi, seseorang akan memperoleh ilmu pengetahuan secara mudah dan juga dapat diyakini kebenarannya.

Perpustakaan sebagai suatu lembaga yang mengelola informasi harus bisa menyediakan informasi yang dibutuhkan pengguna. Menurut SulistyoBasuki dalam bukunya Pengantar Ilmu Perpustakaan mengatakan bahwa :

Perpustakaan adalah sebuah ruangan, bagian sebuah gedung, atau gedung itu sendiri yang digunakan untuk menyimpan buku dan terbitan lainnya yang biasanya disimpan menurut tata susunan tertentu untuk digunakan pembaca, bukan untuk dijual. Dalam pengertian buku dan terbitan lainnya termasuk di dalamya semua bahan cetak (Buku, majalah, laporan, pamflet, prosiding, manuskrip (naskah), lembaran musik, berbagai karya media audiovisual, seperti film, slaide (slide), kaset, piringan hitam, bentuk mikro seperti mikrofilm, mikrofis, dan mikroburam (micropaque). (Sulisyo-Basuki, 1991:3)

Berbicara tentang perpustakaan tinggi di lingkungan Universitas Padjadjaran selain telah berdiri UPT. Perpustakaan Pusat UNPAD. Adapun sebagaimana yang kita ketahui keberadaan perpustakaan pusat dalam sebuah lembaga pendidikan tinggi tujuannya antara lain adalah untuk mendukung pelaksanaan tri dharma perguruan tinggi. Dalam mendukung pelaksanaan tri dharma perguruan tinggi tersebut maka diharapkan perpustakaan pusat UNPAD dituntut untuk mengembangkan koleksinya secara terus menerus, dan harus mengantisipasi akan kebutuhan pemakainya yang selalu meningkat seiring kemajuan perkembangan ilmu pengetahuan dan teknologi. Pengembangan koleksi perpustakaan memerlukan dukungan dana yang mencukupi dari lembaga induk dan kreatifitas pihak manajemen 
perpustakaan untuk menjalankan program-program kegiatan sesuai dengan usulan tersebut.

Dalam hal membangun dan mengembangkan koleksi perpustakaan, harus selaras dengan misi lembaga induknya dimana perpustakaan tersebut berada, tujuan perpustakaan, masyarakat yang dilayaninya, dan sumber dana. Pengembangan koleksi memerlukan perencana yang terpadu agar efektif, efisien dan tepat guna sesuai kebutuhan penggunanya dan baik rencana jangka pendek maupun rencana jangka panjang.

Pengembangan koleksi merupakan hal yang sangat penting bagi kelangsungan perpustakaan dan untuk meningkatkan mutu koleksinya agar perpustakaan tidak ditinggalkan oleh pengguna yang selalu menginginkan akan informasi-informasi terbaru. Pengembangan koleksi berorientasi sesuai dengan kebutuhan masyarakat yang dilayani dengan koleksi-koleksi yang sesuai dengan perkembangan zaman. Orientasi pengembangan koleksi tentunya memperbaharui dan menglengkapi koleksi yang sudah dimiliki, dan untuk memperbaiiki kelemahan-kelemahan yang ada. Hal ini sesuai dengan yang dikatakan Soeatminah (1992:67) yang menyatakan salah satu prinsip pembinaan koleksi yang perlu diperhatikan adalah prinsip kemutakhiran, maksudnya bahan pustaka yang dihimpun hendaknya sesuai dengan perkembangan ilmu pengetahuan, informasi dan teknologi agar pemakai dapat memperoleh informasi yang sesuai dengan perkembangan zaman.

Dalam melakukan pengembangan koleksi menurut Evans dan Saponaro (2005: 8) terdapat enam tahapan, dimana salah satu tahapannya adalah kegiatan penyeleksian. Dalam melakukan penyeleksian bahan pustaka seorang pustakawan dipengaruhi oleh falsafah seleksi yang diyakininya serta cara mendayagunakan alat bantu seleksi bahan pustaka secara tepat, karena dengan informasi yang diperoleh dari tahapan hasil analisis kebutuhan diharapkan mampu memanfaatkan alat bantu dan verifikasi yang tepat sehingga akan mampu menyediakan bahan pustaka yang sesuai dengan kebutuhan, tunutan dan selera masyarakat penggunanya yakni para sivitas akademika yang ada di lingkungan UNPAD. 
Penelitian ini mengkaji tentang pendayagunaan alat bantu seleksi yang dilakukan para pustakawan yang ada di UPT. Perpustakaan Pusat Universitas Padjadjaran.

\section{Perumusan Masalah}

Berdasarkan paparan yang telah dikemukakan dalam latar belakang di atas, maka dapat dirumuskan masalah sebagai berikut:"Bagaimana pendayagunaan alat bantu seleksi bahan pustaka oleh para pustakawan di UPT. Perpustakaan Pusat Universitas Padjadjaran dalam kegiatan pengembangan koleksi ?".

\section{Fokus Penelitian}

Adapun yang menjadi fokus penelitian yang ingin diteliti didalam penelitian ini adalah :

1) Bagaimana prosedur penyeleksian bahan pustaka yang dilakukan para pustakawan UPT. Perpustakaan Pusat Universitas Padjadjaran.

2) Bagaimana penggunaan alat bantu seleksi bahan pustaka dalam melakukan kegiatan pengembangan koleksi oleh para pustakawan UPT. Perpustakaan Pusat Universitas Padjadjaran. .

3) Faktor apa saja yang menjadi pertimbangan pustakawan UPT. Perpustakaan Pusat Universitas Padjadjaran dalam menggunakan jenis alat bantu seleksi bahan pustaka.

4) Apa yang menjadi kendala/hambatan dalam melakukan kegiatan seleksi bahan pustaka di UPT. Perpustakaan Pusat Universitas Padjadjaran

4. Tujuan Penelitian

Berdasarkan fokus penelitian diatas, maka penelitian ini bertujuan untuk

1) Untuk mengetahui prosedur penyeleksian bahan pustaka yang dilakukan para pustakawan UPT. Perpustakaan Pusat Universitas Padjadjaran.

2) Untuk mengetahui penggunaan alat bantu seleksi bahan pustaka dalam melakukan kegiatan pengembangan koleksi oleh para 
pustakawan UPT. Perpustakaan Pusat Universitas Padjadjaran. .

3) Untuk mengetahui faktor apa saja yang menjadi pertimbangan pustakawan UPT. Perpustakaan Pusat Universitas Padjadjaran dalam menggunakan jenis alat bantu seleksi bahan pustaka.

4) Untuk mengetahui kendala/hambatan yang dihadapi pustakawan dalam melakukan kegiatan seleksi bahan pustaka di UPT. Perpustakaan Pusat Universitas Padjadjaran

5. Manfaat Penelitian

1) Manfaat Teoritis

Penelitian ini diharapkan dapat memberi masukan bagi bidang kajian ilmu informasi dan perpustakaan khususnya mengenai kegiatan pengembangan koleksi di perpustakaan dan dapat memberi sumbangan pemikiran bagi penelitian ini lebih lanjut.

2) Manfaat Praktis

Penelitian ini diharapkan dapat memberi masukan kepada para pengambil kebijakan dan para pustakawan perpustakaan pusat Universitas Padjadjaran dalam melakukan pengembangan koleksi.

\section{Metode Penelitian}

\section{Metode Penelitian}

Pendekatan yang digunakan dalam penelitian ini menggunakan pendekatan kualitatif dengan jenis penelitian kualitatif. Adapun mengenai fenomenologi menurut Littlejohn dalam Kuswarno $((1999,199)$ mengartikan fenomenologi sebagai studi tentang pengalaman yang datang dari kesadaran atau cara kita memahami sesuatu dengan secara sadar mengalami sesuatu tersebut.

Masih tentang fenomenologi, Kuswarno (2009) menambahkan bahwa prinsip fenomenologi berkenaan dengan pemahaman tentang bagaimana keseharian, dunia intersubyektif (dunia kehidupan) atau juga disebut Lebenswelt terbentuk. Fenomenologi bertujuan mengetahui bagaimana kita menginter-pretasikan tindakan sosial kita dan orang lain sebagai sebuah yang 
bermakna (dimaknai) dan untuk merekonstruksi kembali turunan makna (makna yang digunakan saat berikutnya) dari tindakan yang bermakna pada komunikasi intersubjektif individu dalam dunia kehidupan sosial. Jadi berdasarkan pengertian fenomenologi tersebut di atas, penelitian ini bertujuan untuk mengetahui pandangan dan pengalaman pustakawan perpustakaan pusat Universitas Padjadjaran dalam menggunakan alat bantu seleksi bahan pustaka.

\section{Sumber Data}

Sumber data dalam penelitian ini terdiri dari data primer dan data sekunder. Adapun mengenai kedua sumber data tersebut dapat dikemukakan sebagai berikut :

1) Sumber data primer dalam penelitian ini adalah sumber dari hasil observasi dan wawancara dengan key informan penelitian seperti kepala perpustakaan pusat UNPAD, pustakawan serta pakar pengembangan koleksi dari kelompok akademisi dan praktisi.

2) Sumber data sekunder, yaitu sumber data yang berasal dari dokumen dan literatur lain yang dipakai peneliti dalam menunjang kegiatan penelitian ini.

\section{Teknik Pengumpulan Data}

Dalam penelitian ini ada beberapa teknik pengumpulan data yang dilakukan yakni sebagai berikut :

1) Observasi yaitu teknik pengumpulan data dengan cara pengamatan secara langsung dari lapangan terhadap objek yang diteliti dengan meneliti dan mempelajari bukti-bukti atas data mengenai masalah yang dibahas.

2) Wawancara Mendalam yaitu teknik wawancara bersifat fleksibel, tingkat pengembalian jawaban oleh responden tinggi, urutan dan susunan pertanyaan dapat dikontrol oleh peneliti atau pewawancara.

3) Studi kepustakaan, yaitu proses pengumpulan data yang dilakukan dengan cara mengumpulkan dokumen yang dibutuhkan dalam penelitian, seperti gambaran umum, struktur organisasi, dan lain-lain. 


\section{Teknik Analisis Data}

Analisis data proses mengorganisasian dan mengurutkan data ke dalam pola, kategori. Berkaitan dengan hal ini Moleong (2006) menyebutkan tidak ada cara tertentu yang dapat dijadikan pegangan bagi semua penelitian. Namun dalam analisis data biasanya ada beberapa tahapan seperti tahap reduksi data, tahap display data, tahap mengambil kesimpulan dan tahap verifikasi data.

\section{Hasil Penelitan}

\section{Hasil Penelitian}

Hasil penelitian mengenai pendayagunaan alat bantu seleksi bahan pustaka oleh pustakawan dalam kegiatan pembembangan koleksi di perpustakaan pusat Universitas Padjadjaran dapat dikemukakan hasil sebagai berikut :

1) Prosedur Penyeleksian Bahan Pustaka

Untuk prosedur penyeleksian bahan pustaka yang dilakukan di perpustakaan pusat Universitas Padjadjaran diawali dari masukan dan saran dari para pengguna perpustakaan baik yang bersifat lisan maupun tulisan yang diterima oleh bagian layanan sirkulasi dan layanan referensi. Selanjutnya dari berbagai saran dan masukan tersebut melakukan inventarisasi bahan pustaka yang dibutuhkan para pengguna dengan memperhatikan inventarisasi bahan pustaka yang dibutuhkan para pengguna dengan memperhatikan beberapa kriteria buku yang diseleksi. Ada beberapa kriteria yang menjadi pijakan petugas di bagian pengembangan koleksi perpustakaan pusat UNPAD dalam melakukan seleksi bahan pustaka terutama koleksi buku yaitu :

a) Tujuan, cakupan dan kelompok pembaca.

Kriteria pertama yang diperhatikan pustakawan perpustakaan pusat UNPAD dalam melakukan penyeleksian buku yaitu dengan memperhatikan tujuan dari penulisan buku tersebut. Gambaran mengenai tujuan akan terlihat dari judul, daftar isi, ideks maupu uraian singkat dalam sampul buku atau blurbs. Aspek lainnya yang diperhatikan adalah 
cakupan dari buku tersebut serta informasi yang menjelaskan sasaran dari pembaca buku tersebut. Dengan memperhatikan tujuan, cakupan dan kelompok pembaca dari buku tersebut petugas di bagian pengembangan koleksi bisa mempertimbangkan apakah buku yang diseleksi bisa diusulkan untuk sebagai koleksi perpustakaan pusat UNPAD.

b) Tingkat kesulitan.

Pertimbangan lainnya yang menjadi perhatian pustakawan perpustakaan pusat UNPAD dalam melakukan seleksi adalah tingkat kesulitan dari buku tersebut. Untuk melihat tingkat kesulitan dari bahan pustaka yang akan diseleksi yang lazim dilakukan petugas perpustakaan perpustakaan pusat UNPAD adalah dengan melihat nama penerbitnya, jenis buku yang diterbitkan, subjek serta pengarang dari buku tersebut. Petugas perpustakaan biasanya tahu untuk jenis penerbit tertentu dan subjek bidang ilmu tertentu biasanya mempunyai tingkat kesulitan yang berbeda.

c) Otoritas, kejujuran dan krebilitas pengarang.

Faktor ketiga yang menjadi pertimbangan pustakawan perpustakaan pusat UNPAD dalam melakukan penyeleksian bahan pustaka adalah berkaitan dengan otoritas, kejujuran dan kredibiltas dari pengarang. Berkaitan dengan faktor otoritas, kejujuran dan kredibilitas pengarang ini berdasarkan hasil wawancara yang dilakukan dengan pustakawan perpustakaan pusat UNPAD, biasanya melihat track record pengarang buku yang akan diseleksi, pendidikan formal, pengalaman menulis, karya yang dihasilkan, dll.

d) Bidang subjek

Faktor berikutnya yang menjadi perhatian pustakawan perpustakaan pusat UNPAD dalam melakukan seleksi bahan pustaka yaitu faktor subjek. Berkaitan dengan hal ini dalam melakukan seleksi buku bidang subjek yang diseleksi akan menjadi pertimbangan, artinya jika buku yang diseleksi merupakan subjek yang sedang menjadi prioritas pengadaan atau ada permintaan dari para pengguna atau fakultas untuk pengadaan subjek tertentu, maka buku tersebut akan menjadi daftar buku yang diusulkan. 
e) Perbandingan

Aspek lainnya yang menjadi kriteria yang dilakukan petugas perpustakaan pusat UNPAD dalam menyeleksi buku yaitu dengan melakukan perbandingan, jika terdapat dua buku atau lebih yang membahas topik yang sama maka pihak perpustakaan akan membandingkan dari beberapa hal cakupann, tujuan dan kaitannya dengan kelompokpembaca di perpustakaan tersebut. Dengan melakukan perbandingan ini petugas bisa memutuskan apakah buku tersebut akan diusulkan dalam daftar pengadaan atau tidak.

f) Faktor waktu

Dalam melakukan penyeleksian buku, petugas pengembangan koleksi perpustakaan pusat UNPAD juga mempertimbangkan aspek waktu, artinya untuk buku ilmu pengetahuan dan teknologi biasanya faktor waktu lebih diperhatikan, misalnya untuk buku-buku komputer faktor waktu lebih diperhatikan karena perkembangan teknologi komputer perkembangannya sangat cepat. Sedangkan untuk buku-buku bidang humaniora apalagi buku bidang sejarah faktor waktu kurang begitu diperhatikan.

g) Format Fisik.

Dalam melakukan penyeleksian buku, petugas perpustakaan pusat UNPAD juga memperhatikan format fisik buku. Dalam aspek fisik yang diperhatikan menyangkut kualitas cetak, kualitas kertas, huruf yang digunakan, kualitas refroduksi illustrasi foto serta kualitas jilid.

h) Faktor Harga

Dalam kegiatan pengembangan koleksi yang berjalan di lingkungan UNPAD, meskipun tahap pengadaan atau pembelian buku tidak dilakukan oleh perpustakaan pusat UNPAD namun dalam penyeleksian buku faktor harga tetap dijadikan pertimbangan, artinya jika ada dua buku atau lebih dengan topik yang sama, dengan kriteria-kriteria lainnya yang tidak terlalu jauh berbeda namun harganya ada perbedaan, maka akan dipilih yang harganya lebih murah. Dengan pertimbangan ini 
setidak-tidaknya dengan jumlah anggaran yang sudah ditentukan, kita bisa mengajukan buku jumlah buku lebih banyak lagi.

i) Menunjang kurikulum

Dalam pelaksanaan pendidikan di UNPAD hampir semua fakultas menerapkan kurikulum berbasis kompetensi (KBK). Berkaitan dengan hal ini dalam melakukan penyeleksian buku petugas pengembangan koleksi perpustakaan pusat UNPAD melihat apakah buku yang sedang diseleksi ini menunjang kurikulum yanng dilaksanakan saat ini. Dalam proses seleksi bahan pustaka kriteria ini merupakan penilaian objektif penyeleksian buku untuk perpustakaan perguruan tinggi.

j) Permintaan

Dalam penyeleksian buku, pihak perpustakaan pusat UNPAD juga mempertim-bangakan aspek permintaan pengguna. Perminaatn pengguna akan dikabulkan dan buku yang menjadi permintaan akan didaftarkan dalam usulan buku fisik untuk pengadaan jika kriteriakriteria lainnyaa terpenuhi. Jadi faktor permintaan pengguna ini menjadi pertimbangan terakhir dalam penyeleksian buku di perpustakaan pusat UNPAD.

Selain prosedur penyeleksian untuk koleksi yang berupa buku, pustakawan perpustakaan pusat UNPAD menjelaskan prosedur penyeleksian untuk koleksi yang berupa majalah meliputi beberapa tahap antara lain :

a) Usulan penyediaan majalah bisa datang dari dosen, mahasiswa, lembaga di lingkungan UNPAD, fakultas maupu inisiatif dari pustakawan perpustakaan pusat UNPAD.

b) Pengusul dapat menyampaikan usulannya dengan mengisi formulis yang disediakan perpustakaan pusat UNPAD engan mengisi bibliografi secara lengisi formulis yang disediakan perpustakaan dengan mengisi bibliografi secara lengkap seperti judul majalahnya, nama dan alamat penerbit, frekuensi terbit, ISSN seperti judul majalahnya, nama dan alamat penerbit, frekuensi terbit, ISSN serta harganya.

c) Setelah formulir diterima perpustakaan pusat UNPAD, selanjutnya pihak 
petugas di bagian pengembangan koleksi perpustakaan pusat UNPAD melakukan verifikasi dengan melihat :

- Memeriksa dan melengkapi data bibliografi yang dari setiap majalah yang diusulkan;

- Petugas melakukan pencocokan judul-judul majalah yang akan diusulkan dengan malajah yang sudah dilanggan atau dimiliki perpustakaan CISRAL. Dari pengecekan ini akan diketahui apakah judul majalah tersebut sudah dimiliki atau belum atau sddang ada dalam proses pemesanan (on-order file).

- Dari daftar usulan judul-judul majalah tersebut dilihat juga anggaran yang tersedia, jika dana tidak mencukupi judul malajah yang belum bisa didanai dibuatkan "kartu desiderata", artinya judul-judul majalah dalam jajaran desiderata akan dipertimbangkan jika tersedia dana.

d) Setelah dilakukan verifikasi; hasil keputusan dipenuhi atau belum dipenuhinya usulan majalah tersebut selanjutnya akan disampaikan pada pengusul melalui pimpinan perpustakaan pusat UNPAD.

Faktor lainnya dalam prosedur penyeleksian yang dilakukan perpustakaan pusat UNPAD adalah mengenai peran petugas di bagian pengembangan koleksi hanya bertugas untuk menyusun prioritas yang akan dibeli. Sedangkan tahap pengadaan bahan pustaka yakni berupa pembelian ditangani oleh Biro Umum yakni oleh kepala urusan rumah tangga dan perlengkapan.

2) Penggunaan Alat Bantu Seleksi

Dalam melakukan seleksi bahan pustaka ada beberapa alat bantu seleksi yang digunakan. Untuk lebih jelasnya mengenai penggunaan alat bantu seleksi untuk setiap jenis bahan pustaaka dapat dikemukakan sebagai berikut :

a) Alat Bantu Seleksi Untuk Koleksi Buku.

Ada beberapa alat bantu seleksi yang biasa digunakan pustakawan perpustakaan pusat UNPAD dalam melakukan penyeleksian koleksi berupa buku yaitu : 
- Katalog penerbit. Dalam katalog penerbit biasanya berisi berbagai informasi mulai judul buku, pengarang, harga sampai informasi sekilas mengenai topik yang dibahas dalam buku tersebut. Mengenai katalog buku ini biasanya penerbit dalam setiap enam bulan atau setahun sekali mengirim katalog penerbit ke perpustakaan;

- Bibliografi Nasional Indonesia (BNI) atau bibliografi internasional untuk buku. Dalam bibliografi biasanya menyajikan informasi mengenai buku-buku yang diterbitkan pada wilayah tertentu. Di Indonesia Bibliografi diterbitkan oleh Perpustakaan nasional RI. Dalam Bibliografi informasi yang disajika yaitu meliputi judul, pengarang, penerbit, tahun terbit, serta nomor klasifikasi. Katalog Induk Nasional (Union Catalog). Dalam katalog induk nasional ini informasi yang disajikan hampir sama dengan bibliografi Nasional maupun internasional, hanya dalam bibliografi tidak menunjukkan koleksi tersebut ada atau disimpan dimana, sedangkan dalam katalog induk biasanya merujuk pada tempat dimana perpustakaan yang memiliki buku tersebut.

- Daftar tambahan koleksi dari perpustakaan lainnya (accesion list). Alat bantu ini biasanya menyajikan mengenai daftar buku baru yang dimiliki oleh suatu perpustakaan. Informasi yang disajikan dalam accesion list yaitu mengenai judul buku, pengarang, penerbit dan tahun terbit.

- Tinjauan dan resensi buku. Ada bebera hal yang diperoleh dari resensi dan tinjauan buku ini seperti informasi mengenai nama pengarang, tanggal dan tahun publikasi, keterangan mengenai pengarang apakah pengarang baru atau sudah terkenal, perbandingan antara buku yang satu dengan yang lainnya yang sama typenya, meninjau dan mengkritik buku yang diterbitkan, buku tersebut cocoknya untuk perpustakaan seperti apa dan siapa pemakai buku tersebut

- Indeks, misanya book review digest, book review index, technical book review index. Dalam alat bantu ini biasanya menyajikan daftar 
buku-buku untuk subjek tertentu yang disusun secara alfabetis.

- Katalog buku on-line, seperti Amazon.com, Palasari on-line, dll. Misalnya untuk palasari on-line menyajikan berbagai penerbit yang ada di Indonesia dan menyajikan ribuan buku yang diterbitkan oleh para penerbit di Indonesia.

- GBPP/SAP suatu mata kuliah yang ada di suatu lembaga pendidikan. GBBP dan SAP biasanya menyajikan daftar-daftar buku yang menjadi sumber yang digunakan dalam proses belajar mengajar. Dalam proses penyeleksian bahan pustaka GBPP/SAP juga dapat menjadi salah satu alat untuk memverifikasi buku/bahan bacaan yang harus dimiliki suatu perpustakaan.

- Resources person atau nara sumber, yaitu alat bantu seleksi yang berupa orang atau pakar yang bisa diminta pendapatnya atau rekomendasinya.

b) Alat Bantu Seleksi Untuk Majalah

Untuk penyeleksian bahan pustaka berupa majalah dan jurnal, menurut pustakawan perpustakaan pusat UNPAD ada beberapa alat bantu seleksi yang digunakan yakni sebagai berikut :

- Katalog penerbit dalam dan luar negeri, para penerbit biasanya mengedarkan katalog dari judul-judul majalah yang diterbitkan sebagai promosi.

- Bibliografi nasional maupun internasional untuk majalah. Secara ideal sarana bibliografi untuk seleksi majalah sebaiknya dikelompokkan menurut subjeknya.

3) Pertimbangan Dalam Menggunakan Alat Bantu Seleksi Bahan Pustaka.

Di perpustakaan pusat UNPAD sebenarnya telah tersedia berbagai jenis alat bantu seleksi seperti daftar katalog penerbit, resensi buku yang terdapat dalam berbagai surat kabar maupun majalah yang dilanggan oleh perpustakaan pusat UNPAD, serta alat bantu seleksi dari media internet. Ada beberapa hal yang menjadi pertimbangan, daftar katalog penerbit dan 
media internet banyak dipakai sebagai alat bantu seleksi antara lain, informasi mengenai daftar buku-buku baru lebih mudah diperoleh dari daftar katalog penerbit dan media internet seperti amazon.com khususnya untuk terbitan luar negeri. Selain itu faktor keterbatasan tenaga yang tidak memungkinkan untuk mengkaji berbagai alat bantu seleksi bahan pustaka yang ada saat ini, serta keterbatasan pengetahuan dan keterampilan para petugas dalam menggunakan berbagai alat bantu seleksi.

4) Hambatan Dalam Penggunaan Alat bantu Seleksi

Mengenai hambatan atau kendala dalam penggunaan alat bantu seleksi yang di perpustakaan pusat UNPAD, berdasarkan hasil wawancara dan pengamatan peneliti di lapangan terungkap bahwa yang menjadi hambatan dalam pengunaan alat bantu seleksi antara lain :

1) Faktor ada sumber daya manusia (SDM). Ada beberapa hal meyangkut faktor tenaga ini yaitu dari aspek kuantitatif yakni jumlah tenaga atau petugas perpustakaan pusat UNPAD di bagian pengembangan koleksi jumlahnya hanya 3 orang, sementara beban kerja sangat berat karena selain mengerjakan kegiatan yang berkaitan dengan pengembangan koleksi seperti melakukan mengumpulkan data dari bagian layanan sirkulasi dan layanan referensi mengenai kebutuhan bahan pustaka, melakukan penyeleksian bahan pustaka untuk diusulkan ke Biro Umum serta melakukan pekerjaan administrasi yakni menyusun daftar buku yang akan disulkan sebagai kebutuhan fisik buku.

2) Faktor kedua yang menjadi penghambat/kendala dalam penggunaan alat bantu seleksi bahan pustaka adalah belum berjalannya kerjasama, baik yang sifatnya internal seperti kerjasama dengan lingkungan perpustakaan fakultas, pembantu Dekan I di lingkungan UNPAD maupun kerjasama dengan perrpustakaan perguruan tinggi lainnya yang tergabung dalam FPT2I. Hal ini terlihat pemanfaatan alat bantu seleksi yang berupa GBPP/SAP yang ada di setiap fakultas belum berjalan. Selain itu juga penggunaan resources person atau nara sumber yang terdapat di setiap fakultas belum dilakukan. Sedangkan yang menyangkut dengan 
kerjasama dengan perpustakaan lainnya adalah belum adanya pertukaran daftar buku-buku baru yang dimiliki setiap perpustakaan (accesion list) sebagai salah satu alat bantj seleksi bahan pustaka.

3) Faktor ketiga yang menjadi pengambat dalam penggunaan alat bantu seleksi masih terbatasnya alat bantu seleksi yang tersedia di perpustakaan pusat UNPAD. Hal ini terlihat pada saat melakukan penyeleksian bahan pustaka hanya menggunakan alat bantu seleksi tertentu saja seperti katalog penerbit padahal masih banyak alat bantu seleksi lain yang seharusnya bisa dimanfaatkan.

\section{Pembahasan}

Koleksi yang baik merupakan salah satu syarat dalam memberikan jasa informasi yang baik, seperti yang dikemukakan oleh Katz sebagaimana yang dikutif Pawit M Yusup (1989) bahwa salah satu tugas utama perpustakaan adalah mengembangkan koleksi yang tepat, untuk pembaca yang tepat, dan pada waktu yang tepat. Kegiatan pengembangan koleksi sebagai salah satu bagian kegiatan dari penyelenggaraan sebuah perpustakaan, termasuk dalam hal ini Perpustakaan Umum. Kegiatan pengembangan koleksi adalah proses pengidentifikasian kekuatan dan kelemahan suatu koleksi perpustakaan dalam rangka memenuhi kebutuhan penggunanya serta upaya untuk memperbaiki kelemahan yang ada dalam perpustakaan tersebut (Evans dan Saponaro, $2005: 5$ ).

Pengembangan koleksi perpustakaan harus mempertimbangkan minat masyarakat yang dilayani. Oleh karena itu pemilihan bahan pustaka harus berpedoman pada kriteria yang sesuai dengan fungsi dan kedudukan perpustakaan. Beberapa tahapan dalam pengembangan koleksi menurut Evans dan Saponaro (2005: 14) terdiri dari :

1) Community Analysis (analisis pemakai) yaitu tahap awal proses pengembangan koleksi untuk melihat siapa segmentasi pengguna perpustakaan. Biasanya dipengaruhi oleh faktor sosial, budaya, tingkat pendidikan, sosial ekonomi, minat baca, usia, dan jenis kelamin. sedangkan secara non formal dapat dilakukan dengan cara mengkaji berbagai terbitan dan 
sumber informasi yang ada untuk kepentingan pengguna.Intinya analisis masyarakat ini dilakukan untuk mendapatkan data yang akurat tentang kebutuhan informasi dari masyarakat atau pemakai yang akan dilayani oleh perpustakaan yang bersangkutan

2) Kebijakan pengembangan koleksi ini berupa dokumen tertulis yang berkaitan dengan pengembangan koleksi. Dalam kebijakan ini biasanya menyangkut masalah bahan pustaka yang akan dikembangkan, anggaran/ dana dan prioritas pengadaan jenis koleksi. Pada dasarnya semua pemakai perpustakaan mempunyai wewenang untuk mengusulkan atau memilih bahan pustaka. Namun keputusan akhir tetap ada di tangan pustakawan yang mengetahui secara langsung keadaan koleksi perpustakaan, anggaran yang tersedia dan skala prioritasnya.

3) Seleksi bahan pustaka pada intinya adalah suatu kegiatan memilih bahan pustaka mana yang sesuai masuk ke perpustakaan sesuai dengan jenis perpustakaan.

4) Akuisisi adalah suatu proses kegiatan pengadaan bahan yang dibutuhkan dengan pembelian, hadiah, hibah, tukar-menukar, menerbitkan sendiri, dan titipan.

5) Penyiangan atau deseleksion adalah merupakan kegiatan yang berkaitan dengan penarikan bahan pustaka dari tempatnya atau rak buku. Kegiatan ini didasarkan oleh beberapa pertimbanganseperti faktor fisik misalnya bukunya sudah rusak, halamannya sudah tidak lengkap, jilidnya lepas, dll, faktor isi misalnya sudah ada edisi baru, sudang kurang relevan, dll, serta karena faktor politik.

6) Evaluasi koleksi adalah kegiatan menilai koleksi perpustakaan baik dari segi ketersediaan koleksi itu bagi pengguna maupun pemanfaatan koleksi itu oleh pengguna. Oleh karena itu evaluasi merupakan kegiatan yang penting yang harus dilakukan di perpustakaan, melalui kegiatan evaluasi kita bias mengetahui bagaimana keadaan perpustakaan. Evaluasi bias dijadikan sebagai dasar untuk perbaikan koleksi agar koleksi yang tersedia benar-benar membantu dan sesuai dengan kebutuhan pemakai. 
Kemudian sebagaimana yang dikemukakan di atas, salah satu tahapan dalam pengembangan koleksi (collection development) adalah melakukan seleksi. Dalam tahapan seleksi ada beberapa hal yang harus menjadi pertimbangan antara lain penggunaan alat bantu seleksi yang digunakan oleh pustakawan dalam melakukan kegiatan seleksi.

Berbicara tentang alat bantu seleksi, alat bantu seleksi bahan pustaka merupakan alat yang sangat penting dalam melakukan seleksi bahan pustaka. Melalui alat bantu seleksi bahan pustaka pustakawan dapat memutuskan jenis bahan pustaka yang akan dipilih karena informasi yang diberikan dalam alat tersebut tidak terbatas pada data bibliografi, tetapi juga mencakup keterangan mengenai isi bahan pustaka tersebut, dan keterangan lain yang diperlukan untuk mengambil keputusan (Yuyu Yulia, 1994:30). Adapun secara umum alat bantu seleksi bahan pustaka meliputi:

1) Alat Bantu Seleksi Bahan Buku

a. Katalog Penerbit dari berbagai penerbit baik dalam negeri maupun penerbit luar negeri

b. Tinjauan Buku, yang dimuat dalam majalah ilmiah, surat kabar, dan majalah populer.

c. Daftar Buku IKAPI

d. Bibliografi Nasional Indonesia

2) Alat Bantu Seleksi untuk Koleksi Serial (Terbitan Berkala)

a. Ulrich's International Periodical Directory. Vol 1-1932. New York;R.R Bowker.

\section{Kesimpulan dan Saran}

\section{Kesimpulan}

1) Untuk prosedur penyeleksian bahan pustaka dimulai dari berbagai saran, masukan baik lisan maupun tertulis ke bagian layanan sitkulasi, layanan referensi maupun layanan majalah. Selanjutnya bagian pengembangan koleksi mengajukan usulan kebutuhan koleksi buku fisik.

2) Penggunaan alat bantu seleksi oleh petugas perpustakaan pusat UNPAD 
belum berjalan secara optimal, artinya dari beberapa alat bantu yang tersedia saat ini alat bantu yang dipergunakan hanya yang berupa katalog penerbit, daftar katalog dalam media internet seperti amazon.com.

3) Ada beberapa alasan pihak perpustakaan pusat UNPAD dalam menggunakan beberapa alat bantu seleksi tertentu seperti katalog penerbit dan katalog dalam media internet yakni faktor kemudahan dalam penggunaan lat bantu tersebut.

4) Mengenai hambatan perpustakaan pusat UNPAD dalam menggunakan alat bantu seleksi yaitu keterbatasan jumlah tenaga yakni hanya memiliki tiga (3) orang petugas di bagian pengembangan koleksi yang harus mengerjakan pekerjaan penyeleksian dan juga pengolahan bahan pustaka.

\section{Saran-saran}

1) Untuk menghasilkan koleksi yang benar-benar sesuai dengan kebutuhan masyarakat pengguna, sebaiknya pihak perpustakaan pusat UNPAD melakukan kajian ilmiah tentang kebutuhan pengguna, selain dari masukan dari para pengguna aktif lainnya.

2) Untuk menghindari koleksi yang diajukan oleh perpustakaan pusat UNPAD tidak tersedia di penerbit atau suplier dan koleksi sebaiknya ada koordinasi yang baik antara pihak perpustakaan dan Kaur Rumah Tangga dan perlengkapan, sehingga koleksi yang diganti adalah merupakan merupakan sepengathuan pihak perpustakaan pusat UNPAD yang mengusulkan.

3) Masih belum optimalnya penggunaan alat bantu seleksi oleh petugas perpustakaan disarankan perlu adanya pelatihan atau penataran tentang cara penggunaan alat bantu seleksi.

4) Dengan semakin bertambahnya beban tugas di bagian pengembangan koleksi yang tidak hanya mengurus penyeleksian bahan pustaka dan juga melakukan pengolahan bahan pustaka, diharapkan adanya tambahan tenaga petugas minimal 8 orang yang masing-masing sebanyak 4 orang di bagian penyeleksian dan 4 orang lagi di bagian pengolahan. Sehingga dengan demikian, penyeleksian dapat dilakukan lebih cermat dan menggunakan berbagai alat bantu seleksi yang seseuai. 


\section{Daftar Pustaka}

H.S, Lasa. 1990. Kamus Istilah Perpustakaan, Yogyakarta : Kanisius.

Daryanto, 1986. Pengetahuan Praktis Bagi Pustakawan, Bandung: Bina Cipta

Evans, G Edward. 2000. Developing Library and Information Center Collection. New York : Library Unlimited.

Evans, G. Edward and Saponaro, Margaret Zarnosky. 2005. Developing Library And Information Center Collections, Fourth Ed, New Yor : Libraries Unlimited, Inc.

Katz, William A. 1989. Collection development: the selection of material for library. New York: Holt Renehart and Winston

Moleong, Lexy J. 1989. Metode Penelitian Kualitatif. Bandung : Remadja Rosda Karya.

Nasution, S. 1988. Metode Penelitian Naturalistik Kualitatif. Bandung: Tarsito.

Nazir, Moch. 1999. Metode Penelitian, Jakarta : Ghalia Indonesia.

Rakhmat, Jalaluddin. 1989. Metode Penelitian Komunikasi. Bandung : Remadja Rosda Karya.

Riyanto, Yatim. 1996. Metode Penelitian Pendidikan, Surabaya : YIS.

Saifuddin, Azwar.1997. Metodologi Penelitian, Yogyakarta : Andi Offset.

Sinaga, Dian. 2005. Modul Pengembangan Koleksi, Bandung : FIKOM UNPAD.

Soeatminah. 1992. Perpustakaan kepustakawanan dan Pustakawan, Yogyakarta: Kanisius.

Sulsityo-Basuki, 991. Pengantar Ilmu Perpustakaan, Jakarta : Gramedia Pustaka Utama.

Sulistyo-Basuki. 1992. Teknik dan Jasa Dokumentasi. 1992, Jakarta : Gramedia Pustaka Utama.

Suryana KW, Idris. 1983. Menseleksi Pustaka Yang Tepat Untuk Perpustakaan Perguruan Tinggi, Bandung : UPT Perpustakaan IKIP.

Trimo, Soejono. 1990. Pedoman Pelaksanaan Perpustakaan. Bandung : Remadja Rosdakarya 
Trimo, Soejono. 1986. Pemilihan Dan Pengadaan Bahan Pustaka, Bandung: Angkasa.

Tjitro Pranoto, Prabowo.1997. Keperluan Peningkatan Keahlian Pustakawan, Bandung: Binacipta.

Waluyo, A.D.,1997. Manfaat Seleksi Bahan Pustaka. Majalah Media Pustakawan Vol 63 dan 4, Hal 41-45

Yin, Robert K. 2005. Studi Kasus, Bandung : Bina Cipta.

Yusup, Pawit M. Komunikasi Pendidikan dan Komunikasi Instruksional, PT. Remaja Rosdakarya, Bandung, 1990.

Yulia, Yuyu ; Janti G. Sujana dan Henny Windarti, 1994.Materi Pokok Pengadaan Bahan Pustaka.Jakarta;UT 